\title{
KEBIJAKAN PEMBINAAN ATLET PUSAT PENDIDIKAN DAN LATIHAN PELAJAR DINAS KEPEMUDAAN DAN OLAH RAGA PROPINSI SULAWESI TENGGARA
}

\author{
Oleh:

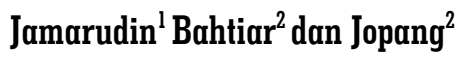 \\ ${ }^{1}$ Mahasiswa Pascasarjana Ilmu Administrasi Publik UHO \\ ${ }^{2}$ Dosen Program Studi Ilmu Administrasi Publik Program Pascasarjana UHO
}

\begin{abstract}
The purpose of this research is to know the policy of coaching athletes Education Center and Student Exercises (PPLP) Department of Youth and Sports in Southeast Sulawesi Province and factors affecting the implementation of the policy. This study used a qualitative approach. Engineering data collection done by the method of document analysis and interviews with informants consisted of representative elements: (1) Responsible youth and Sports Office of PPLP Province Southeast Sulawesi, (2) Chairman PPLP, Coordinator (3). The fields of infrastructure, (4). Coordinator of Field Coaching, (5). Coordinator of the academic field, (6). Coordinator General, Field (7). Dorm Fhui Coordinator, (8). Element trainers (9) Assistant coach and Athlete PPLP (10). The technique of data analysis performed through the stages of data presentation, data reduction and verification/conclusion.

The results showed that in general the policy construction of athletes that includes planning, organizing, training programs and infrastructure, recruitment of athletes and coaches, academic system and funding has not yet been fully implemented by either. Of the seven policy dimensions measured policy exercise program, recruitment of athletes and coaches, as well as academic system, has done well while the planning policy, organizing and infrastructure, as well as funding, runs as expected. This is caused by the policy of coaching athletes PPLP yet implement consistently the whole system approach based on policy criteria of resources (inputs) and internal process approach. Factor skill (skill techniques, skills and conceptual skills of human relationships) is not yet fully owned by PPLP, weak oversight of the institution above the PPLP and administrators who do not yet have a strong moral incentive to use the budgetary resources proportionately in a transparent and accountable.
\end{abstract}

Keywords: Policy, Coaching, Athlete 


\section{PENDAHULUAN}

Pencapaian prestasi olahraga di Propinsi dimulai dari pembinaan prestasi Kabupaten. Olehnya itu potensi bibit-bibit unggul yang ada di daerah harus terus dikembangkan untuk menopang prestasi olahraga di level Propinsi dan Nasional. Undang-Undang RI No. 3 tahun 2005, pasal 33 menyebutkan: "Pemerintah Provinsi melaksanakan kebijakan keolahragaan, perencanaan, koordinasi, pembinaan, pengembangan, penerapan standarisasi, penggalangan sumber daya dan pengawasan.". Hal ini mengandung makna bahwa Pemerintah Propinsi mempunyai tanggung jawab dalam meningkatkan prestasi olahraga secara Nasional melalui pengembangan dan pembinaan olahraga di provinsi, termasuk di Proponsi Sulawesi Tenggara,

Tanggung jawab Pemerintah Propinsi Sulawesi Tenggara yang diberikan oleh Pemerintah untuk pembinaan prestasi atlet/pelajar adalah melalui pembentukan Pusat Pendidikan dan Latihan Pelajar (PPLP). PPLP adalah wadah berhimpunnya atlet/pelajar potensial, mempunnyai bakat, skill, potensi dan kemauan untuk mengasah dan meningkatkan prestasi olahraga. PPLP merupakan unit pembinaan olah raga pelajar yang dibina oleh Dinas Kepemudaan dan Olahraga Propinsi Sulawesi Tenggara. Keberadaan PPLP tersebut sebagai sentra olahraga pendidikan di daerah mempunyai posisi yang stretegis dalam upaya mencetak bibitbibit unggul olahragawan pelajar di daerah. Oleh karena PPLP merupakan lembaga yang bertanggung jawab dalam pembinaan prestasi atlet/pelajar maka sejatinya harus melakukan inovasi kebijakan untuk keberhasilan pembinaan atlet di daerah. Inovasi kebijakan dimaksud adalah kebijakan pembinaan atlet yang berorientasi hasil dan prestasi berdasarkan visi, misi, tujuan dan sasaran otrganisasi. Melalui kebijakan pembinaan atlet PPLP Sulawesi Tenggara peningkatan prestasi atlet harus lebih baik dari pada pembinaan atlet yang sebelumnya penanganan atlet masih menjadi tanggung jawab Dinas Pendidikan dan Kebudayaan.

Berdasarkan hasil observasi data sekunder prestasi binaan cabang olahraga binaan PPLP Dinas Kepemudaan dan Olahraga Propinsi Sulawesi Tenggara selama tiga tahun terakhir terus menunjukkan tren yang terus menurun. Pada Kejuaraan antar PPLP tahun 2015 PPLP Sulawesi Tenggara memperoleh 12 medali, terdiri dari 2 medali emas, 6 medali perak dan 4 medali perunggu. Pada tahun 2016 mengalami peningkatan menjadi 14 medali emas, terdiri dari 3 medali emas, 7 medali perak dan 4 medali perunggu. Sementara itu pada tahun 2017 prestasi PPLP mengalami penurunan yang sangat drastis hanya 8 medali, terdiri dari 1 medali emas. 5 medali perak dan 2 medali perunggu. Sementara pada kejuaraan Pekan Olahraga Nasional (POPNAS) dan Pekan Olahraga Wilayah prestasi PPLP Sulawesi Tenggara juga terus mengalami penurunan. Pada tahun 2015 PPLP Sulawesi Tenggara hanya memperoleh 5 medali terdiri dari 1 emas. 1 perak dan 3 perunggu. Pada tahun 2016 hanya memperoleh 3 medali perak dan pada tahun 2017 juga hanya memperoleh 3 medali perak (Dinas Kepemudaan dan Olahraga Propinsi Sulawesi Tenggara, 2018)

Menurunnya prestasi atlet PPLP tersebut disinyalir oleh adanya beberapa indikasi sebagai berikut : (1). Aspek perencanaan belum melibatkan seluruh pejabat yang ada di PPLP. Perencanaan anggaran masih di dominasi oleh belanja aparatur pengurus PPLP dan sedikit sekali alokasi anggaran untuk pembinaan atlet. (2). Aspek pengorganisasian PPLP sudah baik dan sesuai dengan peraturan perundang-undangan yang ada, namun belum diketahui bagaimana proses hubungan formal antara sesama pegawai maupun pegawai dan atasan dalam struktur organisasi dimaksud. (3). Aspek rekrutmen atlet dan pelatih secara umum sudah sesuai dengan ketentuan yang ada dalam pedoman pengelolaan PPLP, namun kualifikasi dan persyaratan sebagai bukti fisik seperti sertifikat pelatih yang bertaraf nasional beum dapat ditunjukkan sebagai bukti otentik sebagai bagian dari proses tersebut. (4). Aspek sarana dan prasarana 5 (lima) cabang olahraga binaan PPLP secara umum belum layak dan belum memenuhi standar akreditasi nasional untuk penyelenggaraan ivent atau kejuaraan. (5). Aspek kegiatan latihan, secara administrasi sudah ada jadwal tahunan, mingguan dan harian, namun masih perlu dilakukan kajian mendalam mekanisme pelaksanaan latihan tersebut (6) Aspek akademik, sudah ada biodata atlet binaan PPLP tetapi belum dapat dipastikan apakah sistem akademik terlaksana sesuai dengan 
rambu-rambu dalam sistem akademik yang ada. (7) Aspek pendanaan, dari pengamatan yang ada menunjukkan masih belum terbuka (tansparan) anggaran-anggaran yang diperuntukkan kegiatan PPLP.

Dari uraian di atas menggambarkan bahwa kebijakan pembinaan atlet PPLP Dinas Kepemudaan dan Olahraga Propinsi Sulawesi Tenggara belum berjalan dengan baik sehingga berimplikasi pada menurunnya prestasi atlet. Sistem pembinaan sangat penting dilakukan dengan harapan atlet mampu memperoleh prestasi yang optimal. Pencapaian prestasi olahraga tertinggi merupakan akibat langsung dari adaptasi organisme terhadap jenis dan metode pelatihan (Lubis dan Evalina, 2007). Untuk mengukur sasaran-sasaran yang telah direncanakan dalam pelaksanaan kebijakan pembinaan atlet, perlu dilakukan studi kebijakan pembinaan atlet tersebut.

\section{KAJIAN TEORI}

\section{Konsep Kebijakan}

Definisi kebijakan menurut Geurts (2012) adalah mekanisme-mekanisme politik, manajemen, finansial, dan administratif yang ditempuh untuk mencapai tujuan-tujuan yang eksplisit. Sedangkan menurut Park (2000:39) kebijakan adalah keputusan, atau seringkali suatu set keputusan yang saling berkaitan, berkenaan dengan pemilihan tujuan-tujuan dan cara-cara (sarana-sarana) untuk mencapai tujuan-tujuan tersebut. Definisi ini menyiratkan bahwa kebijakan berorientasi pada sesuatu maksud dan tujuan, kebijakan terdiri dari pola-pola tindakan untuk ditempuh dari waktu ke waktu, dan merupakan produk dari suatu permintaan akan penyelesaian masalah tertentu. Kebijakan dapat diterapkan pada sektor pemerintah maupun sektor privat, pada organisasi dan kelompok bahkan individual (Geurts, 2012:6). Kebijakan di sektor pemerintah disebut kebijakan publik. Kraft \& Furlong (2004:4) mengemukakan bahwa kebijakan publik dapat didefinisikan dalam beragam cara, tetapi pada dasarnya adalah suatu cara tindakan pemerintah (atau tidak bertindaknya pemerintah) yang diambil sebagai respons terhadap masalah-masalah sosial. Masalah sosial adalah kondisi-kondisi yang dipahami secara umum oleh publik sebagai sesuatu yang tidak dapat diterima dan karena itu memerlukan intervensi.

Definisi kebijakan publik menurut Dye (2001:2-3) adalah apapun yang dipilih oleh pemerintah untuk dilakukan atau tidak dilakukan. Berdasarkan definisi tersebut, kebijakan publik mencakup bukan hanya tindakan pemerintah tetapi juga tidak bertindaknya pemerintah. Jadi, apabila pemerintah memilih untuk melakukan sesuatu, maka tentunya ada tujuan, karena kebijakan publik merupakan tindakan pemerintah. Sebaliknya apabila pemerintah memilih untuk tidak melakukan sesuatu, inipun merupakan kebijakan publik, yang tentunya juga ada tujuan. Dalam ungkapan yang lain, Levin (2009) menyatakan bahwa kebijakan publik dapat positif ataupun negatif. Positif artinya suatu tindakan yang sengaja dipilih, dan negatif artinya suatu keputusan yang sengaja dipilih untuk tidak mengambil tindakan. Pilihan untuk tidak melakukan sesuatu berkenaan dengan masalah publik tertentu oleh para analis disebut sebagai "nonpolicies" (Kraft \& Furlong, 2004:8). Easton dalam Mulyadi (2015) mendefinisikan kebijakan publik sebagai pengalokasian nilai-nilai kepada seluruh masyarakat secara keseluruhan. Sementara Mulyadi (2015) menyebutkan bahwa kebijakan publik merupakan rumusan keputusan pemerintah yang menjadi pedoman guna mengatasi masalah publik yang mempuyai tujuan, rencana dan program yang aka dilaksanakan secara jelas. Kesimpulannya : (l). Kebijakan publik adalah tentang pilihan: pilihan atas tujuan-tujuan; pilihan atas alasan untuk dan di dalam bertindak; pilihan atas instrumen-instrumen; pilihan tentang bagaimana merespon konsekuensi-konsekuensi dari outputs kebijakan (2) Kebijakan pubik pada dasarnya adalah suatu keputusan yang dimaksudkan untuk mengatasi kesalahan, tertentu melakukan kegiatan tertentu atau untuk mecapai tujuan tertentu yang dilakukan oleh institusi yang 
berwenang dalam rangka penyelenggraaan tugas pemerintahan negara dan pembangunan, berlangsung dalam suatu kebijakan tertentu.

Wilson (2006:12) menyatakan bahwa elemen yang lazim dalam definisi kebijakan publik adalah "suatu proses atau rangkaian atau pola dari aktivitas atau keputusan-keputusan pemerintahan yang didesain untuk memecahkan sejumlah masalah publik. Kebijakan publik merefleksikan maksud, tujuan-tujuan, dan nilai-nilai dari pemerintah. ICAEW (2012:10) menyatakan bahwa kepentingan publik adalah segala sesuatu yang dipentingkan bagi publik. Masalahnya, hal-hal yang bermanfaat bagi publik tidak selalu persis sama dengan apa yang mereka anggap penting. Putra (2003:20-21) menyatakan bahwa kepentingan publik dapat didefinisikan dari tiga perspektif. Pandangan rasionalis mengatakan bahwa kepentingan publik adalah kepentingan terbanyak dari total penduduk yang ada. Pandangan idealis mengatakan bahwa kepentingan publik itu adalah hal yang luhur sehingga tidak boleh direka-reka oleh manusia. Pandangan realis mengatakan bahwa kepentingan publik itu adalah hasil kompromi dari bertarungan berbagai kelompok kepentingan.

\section{Konsep Pembinaan Atlet}

Menurut Lutan dkk (2000) pembinaan adalah sebagai usaha mengorganisasi atau cara untuk mencapai suatu tujuan. Pembinaan adalah usaha atau tindakan yang dilakukan untuk mengubah suatu keadaan dengan baik untuk mendapatkan tujuan yang ingin dicapai secara maksimal. Sementara itu Kusnanik, (2013) menjelaskan pembinaan sebagai usaha, atau tindakan dan kegiatan yang dilakukan secara berdayaguna dan berhasil guna untuk memperoleh hasil yang lebih baik. Sedangkan Ruslan (2011) menyebut pembinaan dan pengembangan dalam olahraga melalui tahap pengenalan olahraga, pemantauan, pemanduan, pengembangan bakat dan peningkatan prestasi. Pembinaan dan pengembangan harus dilakukan sebagai proses yang berurutan, berjenjang dan berkelanjutan. (Mulyadi, 2013). Selanjutnya Faster dan Keren (2001) mengungkapkan bahwa pembinaan lebih lanjut ditunjuukkan untuk sisi perilaku manajemen manusia. Penbinaan berarti kegiatan yang dilakukan secara terus menerus, memberikan berbagai arahan dan dukungan. Pembinaan merupakan proses berkelanjutan sebagai suatu cara untuk melakukan pembelajaran dan pengembangan berkelanjutan.

Pembinaan olahraga menjadi sangat penting dilakukan karena olahraga menjadi salah satu komoditas atau aset bangsa yang sangat berharga. Keriahan pertandingan, berkibarnya bendera merah putih dan lagu kebangsaan Indonesia Raya sebagai simbol negara yang dikumandangkan saat kemenangan dalam suatu pertandingan merupakan kebanggaan bangsa. Kondisi ini telah menjadi pengalaman panjang Negara Indonesia dalam mengikuti iven dan kejuaraan tingkat ASEAN, ASIA maupun dunia. Beberapa cabang olahraga yang menjadi unggulan negara kita antara lain bulu tangis, tinju dan dayung terutama dalam ajang olimpiade (Anonim, 2017). Oleh karena itu Wibowo (2015) menyarankan pentingnya pembinaan olahraga baik prestasi maupun rekreasi atau pendidikan keolahragaan harus dioptimalkan.

Pembinaan olahraga yang baik akan menghasilan prestasi yang baik dan memberikan kontribusi dalam berbagai hal, antara lain : (1). Meningkatkan aktivitas perekenomian suatu daerah atau negara. Penongonn dalam jmulah yang besar merupakan sumber potensi ekonomi yang dapat diandalkan dengan memungut retribusi maupu merangsang aktivitas perekonomian yang lain melalui belanja konsumsi pada saat arena kegiatan berlangsung; (2). Menjadi media untuk memperkenalkan bangsa dimata dunia dengan prestasi gemilang yang diraih oleh para atlet; (3). Merangsang pendapatan devisa negara ketika perhelatan kejuaraan diselenggarakan dalam negeri; (4). Sarana untuk mewujudkan rasa nasionalisme kepada setiap warga negara dari berbagai penjuru dunia. Karena itu olahraga menjadi salah satu sektor yang perlu diperhatikan oleh pemerintah untuk terus meraih prestasi dunia dalam setiap cabang olehraga. Berapa hal yang harus 
diperhatikan adalah melakukan singkronisasi atau menyelesaikan permasalahan pelatihan nasional yang dikeluarkan oleh Dinas Pemuda dan Olahraga (DISPORA) atau Komite Olahraga Nasional Indonesia (KONI) dengan Program Atlet Unggulan (PAL) yang dikelurakan oleh Kementerian Negara Pemuda dan Olahraga (KEMENEGPORA), untuk mengefetifkan pembinaan atlet yang lebih berkualitas.

Menurut Danardono (2015) pembinaan atlet yang sistemik, terpadu, terarah dan terprogram dengan jelas merupakan sebuah sistem yang dimensinya terdiri dari : (1) Teredianya atlet potensial (Talented Athletes) yang direkrut secara kompeten dan profesional; (2). Tersedianya pelatih profesional da dapat menerapkan IPTEK dalam melakukan pembinaan terhadap atlet; (3) Tersedianya sarana prasarana dan kelengkaa olahraga yang memadai yang menunjang pelaksanaan pembinaan dan pengembangan kemampuan; (4) Adanya program yang berjenjang dan berkelanjutan, ditunjang oleh anggaran yang mencukupi; (5) Adanya koordinasi dan relasi yang baik antara semua pihak (atlet, pelatih, pembina, penguru, Pengprov, Dinas Pemuda dan Olahraga (Dispora) dan pemerintah yang meiliki visi bersama dalam pengembangan profesionalisme alltet; (6) Adanya tes pengukuran kondisi atlet secara periodik.

\section{FAKTOR-FAKTOR YANG MEMPENGARUHI KEBIJAKAN PEMBINAAN ATLET}

Ada tiga faktor yang mempengaruhi kebijakan pembinaan atlet PPLP Dinas Kepemudaan dan Olahraga Propinsi Sulawesi Tenggara. Ketiga faktor tersebut adalah :

\section{Faktor Keterampilan}

Tiap orang yang menduduki posis dalam hirarki organisasional disebut manajer. Silalahi (2013) menyebutkan bahwa berdasarkan tngkat manajemen dalam hirarki organisasional, manajer dapat dibedakan dalam tiga tipe, yaitu : (1). Manajer tingkat bawah (lowe level manager) atau manajer lini pertama (2). Manajer tingkat menengah (middle level manager) atau manajer lini kedua dan (3) manajer tingkat puncak (top manager) atau disebut manajer lini ketiga. Untuk menjalankan fungsi-fungsi manajemen tersebut tiap manajer membutuhkan keterampilan manajerial (managerial skill) untuk mewujudkan efektivitas dan efisiensi organisasi organisasi. Keberhasilan manajer pada semua tingkat tergantung pada keterampilan manajerial yang mereka miliki. Menurut Robbins, S (1994) dalam Silalahi (2013) keterampilan manajerial adalah specific observable behaviors that effective manager exhibit". Keterampilan (skill) ialah kemampuan (ability) untuk mengubah pengetahuan (knowledge) ke dalam tindakan (action) untuk menghasilkan tingkat kerja yang diinginkan. Keterampilan adalah kompetensi yang berhubungan dengan tugas seperti keterampilan mengoperasikan komputer, atau keterampilan berkomunikasi dengan jelas untuk tujuan dan misi kelompok Gibson, Ivancevich, Donnelly (1996). Setiap pekeraan terjadi dua hal yaitu orang dan tugas kerja. Menccokkan orang dengan tugas pekerjaan yang sesuai dengan kemapuan dan keahlian mereka sering menjadi masalah pengembangan keterampilan yang secara spesifik berkaitan dengan kompetensi dapat berdampak baik pada budaya organisasi dan kompetensi individual (Wibowo: 2007).

Menurut Spencer dan Spencer (1993), keterampilan meliputi : (1). Concern for Order (CO) merupakan dorongan dalam diri seseorang untuk mengurangi ketidakpastian di lingkungan sekitarnya, khususnya berkaitan dengan pengaturan kerja, instruksi, informasi dan data; (2). Initiative (INT) merupakan dorongan bertindak untuk melebihi yang dibutuhkan atau yang dituntut dari pekerjaannya, melakukan sesuatu tanpa menunggu perintah lebih dahulu. Tindakan ini dilakukan untuk memerbaiki dan meningkatkan hasil pekerjaan atau menghindari timbulnua maalah atau menciptakan peluang baru; (3).Impact and Influence (IMP) merupaka tindakan membujuk, meyakinkan, mempengaruhi atau mengesankan sehingga orang lain mendukung agendanya; (4).Information Seeking (INFO) merupakan besarnya usaha tambahan yang dikeluarkan untuk mengumpulkan 
informasi lebih banyak. Seorang aparatur pemerintah sangat ditentukan kinerjanya. Faktor yang menentikan dalam kinerja (performance) seseorang antara lain kompetensi dan keterampilan dan kecakapan bekerja. Oleh karena itu keterampilan merupakan faktor utama yang menunjang kinerja organisasional.

Rober L Katz (1978) dalam Silalahi (2013) ada tiga tipe dasar keterampilan manajerial, yaitu : (1). Keterampilan teknik, yaitu kemampuan atau kompetensi spesifik untuk menggunakan teknik-teknik, alat-alat, prosedurprosedur, metode-metode atau pengetahuan-pengetahuan tentang lapangan yang dispesialisasi secara benar dan tepat dalam pelaksanaan tugasnya; (2). Keterampilan manusia, yaitu kemampuan untuk memahami atau memotivasi orang lain, sebagai individu atau dalam kelompok. Keterampilan hubungan manusia adalah jauh lebih penting dari keterampilan teknis. Kemampuan ini berhubungan dengan kemampuan menseleksi personalia, menciptakan dan membina hubungan baik, memahami orang lain, memberi motivasi dan bimbingan dan mempengaruhi para pekerja, baik secara individu atau kelompok. (3). Keterampilan konseptual, yaitu kemampuan mengkoordinasikan dan mengintegrasikan semua kepentingan-kepentingan dan aktivitasaktivitas organisasi atau kemampuan mental mendapatkan, menganalisis, menginterpretasi informasi yang diterima dari berbagai sumber.

\section{FAKTOR PENGAWASAN}

Sebagaimana telah diuraikan di atas bahwa organisasi tipe manajer dalam suatu organisasi terdiri dari tiga tipe, yaitu : manajer tingkat bawah, manajer tingkat menenengah dan manajer puncak. Setiap tipe manajer tersebut juga berperan sebagai supervisor. Dengan demikiian supervisor adalah majaer yang secara langsung mengkoordinasikan pekerjaan dalam kelompok non manajerial atau personalia dan langsung memanajemeni sumber daya lain, termasuk machinery and materials. Oleh sebab itu penyelia menjadi kunci utama (keystone)atau yang memegang peranan penting dalam organisasi-organisasi modern, baik organisasi publik maupun bisnis.

Penyelia merupakan mediator antara kelompok non manajerial dengan manaajer. Sebagai manajer ia menjalankan aktivitas manajemen meskipun fungsi utamanya adalah pemimpin, mengkoordinasikan dan menggerakkan non manajerial yang disebut personalia secara tertib dan teratur untuk mencapai tujuan organisasinya ke arah yang yang lebih baik. Karena itu supervisor atau pengawas merupakan orang yang paling kompeten dan memiliki posisi terbaik untuk mengetahui dan mengerti apa yang sedang terjadi dalam unit kerjanya. Sebagai bagian dari keseluruhan tim manajemen dalam usaha untuk meningkatkan efisiensi dan efektivitas organisasi, maka peran supervisor atau pengawas adalah meakukan kontrol, memecahkan permasalahan, membuat perencanaan baru, mengkomunikasikan permasalahan dll sebagai bentuk kewajiban fungsi manajemen. Oleh karena itu setiap lini dalam manajemen masing-masing mempunyai uraian tugas sebagai kewajiban dan tanggung jawab dalam pekerjaan (Silalahi, 2013).

Fungsi pengawasan atau pengendalian organisasi sangat penting dalam rangka untuk mengetahui apakah tugas-tgas terlaksana efektif dan sumber daya yang digunakan efisien atau tujuan organisasi tercapai secara efektif dan efisien. Pengawasan merupakan fungsi manajer untuk menjamin bahwa organisasi dan tindakantindakan anggotanya bergerak ke arah tujuan yang sudah ditetapkan. Fungsi pengawasan menjamin untuk pencapaian tujuan. Oleh karena itu pengawasan sangat penting karena merupakan jaringan terakhir dalam fungsi-fungsi manajemen. Pengawasan ini menjadi cara manajer untuk mengetahui apakah tujuan organisasi tercapai atau tidak dan harus ditemukan jawabannya (John A, and Robbinson, 1989).

Lebih lanjut dijelaskan pula bahwa esensi pengawasan oleh institusi yang lebih tinggi terhadap kebijakan pembinaan atlet adalah melakukan kontrol dan feed back terhadap penyimpangan dari keterntuan yang telah 
ditetapkan sebelumnya. Winardi (2003) menyebutkan bahwa pengawasan berarti mengevaluasi prestasi kerja dan jika perlu menerapkan tindakan-tindakan korektif sehingga hasil pekerjaannya sesuai dengan rencanarencana dan ketentuan-ketentuan yang telah ditetapkan dan masih berlaku.

\section{FAKTOR INSENTIF MORAL}

Insentif moral menurut Hulsmann (2006) sebagai kondisi-kondisi dalam diri individu yang tumbuh untuk memotivasi manusia. Insentif moral menunjuk pada kondisi-kondisi moral yang memotivasi tindakan manusia. Istilah motivasi secara etimologi berasal dari kata Latin movere yang berarti menggerakkan. Jadi, motivasi berarti hal-hal yang mendorong atau menggerakkan seseorang untuk melakukan sesuatu (Helms, 2006). Dalam penggunaan sehari-hari, motivasi adalah tentang mengantarkan orang untuk bekerja dengan semaksimum kemampuannya (Kitchin, 2010). Konsep motivasi telah didefinisikan dengan berbagai cara oleh para pakar. Rilley (2005 mendefinisikan motivasi sebagai alasan-alasan yang mendasari perilaku yang ditandai oleh keinginan atau kemauan. Gibson et al. (2012:87) menyatakan bahwa motivasi berhubungan dengan tiga hal, yakni: (1) arah perilaku, (2) kekuatan respons setelah karyawan memilih mengikuti tindakan tertentu, dan (3) ketahanan perilaku, atau berapa lama orang itu terus-menerus berperilaku menurut cara tertentu.

\section{KERANGKA PIKIR}

Kebijakan, menurut Dye dalam Dunn (2003) kebijakan adalah segala sesuatu yang dikerjakan dan yang tidak dikerjakan oleh pemerintah. Sedangkan menurut David Easton dalam Mulyadi (2015) mendefinisikan kebijakan publik sebagai pengalokasian nilai-nilai kepada seluruh masyarakat secara keseluruhan. Pengertian kebijakan yang dimaksud dalam penelitian ini merujuk pada pendapat Mulyadi (2015) bahwa kebijakan pubik adalah rumusan keputusan pemerintah yang menjadi pedoman guna mengatasi masalah publik yang mempunyai tujuan, rencana dan program yang akan diaksanakan secara jelas. Kebijakan publik dilakukan untuk mengatasi kesalahan tertentu dalam kegiatan tertentu atau untuk mencapai tujuan tertentu yang dilakukan oleh institusi yang mempunyai wewenang dalam rangka penyelenggaraan tugas pemerintahan negara dan pembangunan, berlangsung dalam satu kebijakan tertentu.

Menurut Anonim (2017) kebijakan pembinaan atlet yang mendukung prestasi olahraga dilakukan melalui mekanisme yang terdiri dari (1). Perencanaan; (2). Pengorganisasian; (3). Program latihan, (4). Pengelolaan sarana dan prasarana; (5). Rekrutmen atlet dan pelatih; (6). Sistem akademik, dan (7) Pendanaan.

\section{METODE PENELITIAN}

\section{TEMPAT DAN WAKTU PENELITIAN}

Penelitian ini telah dilaksanakan di PPLP Dinas Kepemudaan dan Olahraga Propinsi Sulawesi Tenggara. Pemilihan lokasi tersebut didasarkan pada pertimbangan bahwa prestasi olahraga yang dibina PPLP Dinas Kepemudaan dan Olahraga Propinsi Sulawesi Tenggara dalam tiga tahun terakhir mengalami penurunan sebagaimana diuraikan sebelumnya.

Penelitian ini dilaksanakan selama tiga bulan sejak Bulan Pebruari sampai dengan April 2018. Dalam waktu satu bulan pertama penulis melakukan persiapan-persiapan dan pengenalan konteks penelitian serta studi awal tentang kebijakan yang diadopsi. Dalam satu bulan berikutnya penulis melakukan studi intensif dan menulis laporan awal. Dalam satu bulan berikutnya, penulis berkonsultasi dengan pembimbing, melakukan revisi laporan sesuai dengan hasil-hasil konsultasi, melakukan seminar hasil, ujian akhir, dan penyusunan laporan tesis. 


\section{JENIS DAN SUMBER DATA}

Jenis penelitian ini menggunakan pendekatan kualitatif. dengan metode survey. Sumber data penelitian terdiri dari data primer da data sekunder. Data primer diperoleh langsung dari informan penelitian melalui wawancara langsung, sedangkan data sekunder diperoleh melalui (1). Pedoman seleksi penerimaan atlet/siswa PPLP Dinas Kepemudaan dan Olahraga Prpopinsi Sulawesi Tenggara; (2). Surat Keputusan Pejabat Pembuat Komitmen Satuan Kerja Dinas Kepemudaan dan Olahraga Propinsi Sulawesi Tenggara tahun 2015, 2016 dan 2017, LAKIP Dinas Kepemudaan dan Olahraga Propinsi Sulawesi Tenggara Tahun 2016 dan 2017 dan dokumen lain yang dianggap relevan dengan pembinaan olahraga di PPLP Dinas Kepemudaan dan Olahraga Propinsi Sulawesi Tenggara.

\section{INFORMAN PENELITIAN}

Untuk mendapatkan keterangan informasi yang paripurna selain melalui populasi yang ada, penulis juga menggali informasi melalui informan yang dianggap mengetahui permasalahan pembinaan olahraga di PPLP Dinas Kepemudaan dan Olahraga Propinsi Sulawesi Tenggara. Penentuan informan dilakukan secara sengaja berdasarkan kriteria dan pertimbangan kemampuan, serta kesediaan waktu dan dapat memberikan informasi yang diperlukan dalam upaya menjawab permasalahan dan tujuan penelitian yang diuraikan sebelumnya. Informan dalam penelitian ini sebanyak 10 orang yang mewakili dari berbagai unsur dalam PPLP terdiri dari (1). penanggungjawab PPLP Dinas Kepemudaan dan Olahraga Propinsi Sulawesi Tenggara, (2). Ketua Pelaksana PPLP, (3). Koordinator Bidang Sarana dan Prasarana, (4). Koordinator Bidang Kepelatihan, (5). Koordinator Bidang Akademik, (6). Koordinator Bidang Umum, (7). Koordinator Pengurus Asrama, (8). Unsur Pelatih (9) Asisten Pelatih dan (10) Atlet PPLP.

\section{FOKUS PENELITIAN}

Penelitian ini fokus pada kebijakan pembinaan atlet dan faktor-faktor yang mempengaruhi kebijakan pembinaan olahraga di PPLP Dinas Kepemudaan dan Olahraga Propinsi Sulawesi Tenggara. Kebijakan pembinaan olahraga yang dimaksud dalam penelitian ini meliputi perencanaan, pengorganisasian, program latihan, sarana dan parasarana, rekrutmen atlet dan pelatih, akademik dan pendanaan serta faktor-faktor yang mempengaruhi kebijakan pembinaan atlet PPLP Dinas Kepemudaan dan Olahraga Propinsi Sulawesi Tenggara selama tahun 2015, 2016 dan 2017. Ketiga faktor tersebut adalah : faktor keterampilan, faktor pengawasan dari atasan dan faktor insentif moral.

\section{TEKNIK PENGUMPULAN DATA}

Data dalam penelitian ini dihimpun melalui pengamatan, wawancara dan studi dokumen. Wawancara dengan informan penelitian merupakan teknik utama dalam penelitian ini untuk memperoleh data tentang seluruh aktivitas dan kondisi yang menjadi fokus peneltian ini.

\section{TEKNIK ANALISIS DATA}

Teknik analisis data yang digunakan dalam penelitian ini adalah analisis kualitatif model interaktif sebagaimana yang dikemukakan oleh Miles and Huberman (1994:10-12). Model analisis interaktif ini mencakup analisis data sejak sebelum pengumpulan data, sewaktu proses pengumpulan data sementara dan analisis awal, dan setelah tahap pengumpulan data akhir. Komponen analisis model interaktif terdiri dari : (1). Tahap reduksi data, (2). Tahap penyajian data, (3). Tahap penyajian laporan, dan (4). Tahap kesimpulan dan verifikasi. 


\section{HASIL PENELITIAN DAN PEMBAHASAN}

\section{Gambaran Umum Lokasi Penelitian}

Wilayah penelitian merupakan hal penting untuk diketahui dalam rangka memberikan pendalaman pemahaman terhadap fokus permasalahan yang akan diteliti. Berikut ini adalah gambaran singkat Pusat Pendidikan dan Latihan Pelajar (PPLP) Dinas Kepemudaan dan Olahraga Propinsi Sulawesi Tenggara.

Pusat Pendidikan dan Latihan Pelajar (PPLP) Dinas Kepemudaan dan Olahraga Propinsi Sulawesi Tenggara merupakan wadah berhimpunnya olahraga pelajar potensial berbakat untuk dikembangkan potensinya menjadi olahragawan/atlet pelajar berprestasi tingkat nasional, regional dan internasional. struktur organisasi PPLP terdiri dari : (1). Penanggung jawab, (2). Ketua pelaksana, (3). Bidang-bidang, yang terdiri dari : (a). bidang sarana dan prasarana, (b). bidang pelatihan, (c). bidang akademik, dan (d). bidang umum dan (4). Atlet. Pengurus PPLP Dinas Kepemudaan dan Olahraga Propinsi Sulawesi Tenggara dapat dilihat berdasarkan Surat Keputusan Pejabat Pembuat Komitmen Satker Dinas Kepemudaan dan Olahraga Propinsi Sulawesi Tenggara tahun 2017 Nomor 7 tahun 2017 tanggal 3 Januari 2017 tentang Susunan Pengurus Pusat Pendidikan dan Latihan Pelajar (PPLP) Dinas Kepemudaan dan Olahraga Propinsi Sulawesi Tenggara. Berdasarkan SK tersebut Pengurus PPLP berjumlah 22 orang, dengan perincian 7 orang pengurus, 5 orang pelatih, 10 orang asisten pelatih. Siswa/atlet PPLP berjumlah 66 orang yang tersebar dalam 5 (lima) cabang olahraga, yaitu dayung 20 siswa, pencak silat 13 siswa, sepak takraw 10 siswa, atletik 10 siswa dan taekwondo sebanyak 7 siswa.

\section{KEBIJAKAN PEMBINAAN ATLET PPLP DINAS KEPEMUDAAN DAN OLAHRAGA PROPINSI SULAWESI TENGGARA}

Hasil analisis kualitatif terhadap kebijakan perencanaan yang ada di PPLP belum sepenuhnya terlaksana dengan baik Hal ini disebabkan oleh karena mekanisme perencanaan yang dibuat selama ini masih sentralistik atau berpusat pada penanggung jawab PPLP. Penggunaan dana sebagai impikasi dari perencanaan tersebut belum didasari oleh prinsip-prinsip tata kelola anggaran yang tranparan, akuntabel, partisipatif dan demokratis. Idealnya perencanaan dalam bentuk rencana kerja harus melibatkan bidang-bidang yang ada, dibahas dan disulkan secara kritis dan ditetapkan dalam forum musyawarah Organisasi Perangkat Daerah. Secara teoritis, perencanaan merupakan kegiatan atau tindakan-tindakan manajerial untuk mencapai sasaran yang telah ditetapkan organisasi (Koontz and Weihrich, 1993). Perencanaan yang baik akan dapat mengeliminasi resiko kegagalan. Rencana menentukan kemana organisasi dan kegiatan-kegiatannya akan diarahkan. Dengan demikian bahwa setiap rencana dan semua rencana-rencana turunan adalah membantu pencapaian tujuan organisasi. Lebih lanjut dijelaskan pula perencanaan merupakan dasar untuk pelaksanaan fungsi-fungsi manajemen. Selanjutnya menurut Schermerhorn, et al., (2003) mengemukakan bahwa terdapat beberapa aspek pentingnya perencanaan dalam suatu organisasi, yaitu : (a). Perencanaan dapat memberikan arah bagi manajer dan non manajer sehingga memudahkan mengetahui apa yang harus dikerjakan, apa yang harus disumbangkan untuk mencapai tujuan organisasi; (b). Perencanaan mengurangi ketidak pastian; (c). Perencanaan meningkatkan koordinasi; (d) Perencanaan menetapkan seperangkat standar-standar yang digunakan dalam pengendalian. Oleh karena itu sebaiknya perencanaan harus dapat melibatkan semua elemen yang ada dalam organisasi sesuai dengan kewenangannya masing-masing.

Hasil analisis kebijakan pengorganisasian sudah nampak baik. Hal ini dibuktikan dengan adanya struktur organisasi pengelola PPLP yang jelas sesuai dengan SK Pejabat Pembuat Komitmen Satker Dinas Kepemudaan dan Olahraga Propinsi Sulawesi Tenggara Nomor 7 tahun 2017 dan Pedoman Pengelolaan PPLP Kementerian 
Pemuda dan Olahraga Republik Indonesia Tahun 2017. Handoko (2009) menjelaskan pentingnya struktur organisasi dalam suatu lembaga/organisasi. Struktur organisasi menunjukkan kerangka dan susunan perwujudan pola tetap hubungan diantara fungsi, posisi, maupun orang-orang yang menunjukkan kedudukan, tugas, wewenang dan tanggung jawab yang berbeda-beda dalam suatu organisasi. Secara administrasi jajaran PPLP mulai dari pengurus, pelatih, asisten pelatih dan siswa/atlet mempunyai legalitas formal yang jelas. Demikian pula dengan uraian tugas (job description) masing-masing bidang. Akan tetapi dalam pelaksanaannya belum terwujud dengan baik. Hal ini dapat dilihat dari hubungan-hubungan formal yang ada diantara orang dan uraian tugas dalam suatu organisasi belum terlaksana dengan baik. Padahal hubungan formal tersebut baik hubungan manajerial dan hubungan karyawan di semua tingkatan organisasi harus merupakan satu bagan yang merupakan satu cetak biru (blueprint) dari hubungan-hubungan formal dalam suatu organisasi (Pearce and Robinson, 1989). Namun pada kenyataanya SK tersebut belum dapat dijalankan dengan baik karena mekanisme pelaksanaan tugas berdasarkan pendekatan sistem politik. Pemberian tanggung jawab hanya didominasi oleh beberapa orang yang mempunyai hubungan dan akses politik dengan pimpinan. Kondisi ini berdampak pada tidak berjalannya sistem sebagaimana ketentuan organisasi.

Dari kebijakan ketersediaan Sarana dan prasarana sebagian besar informan mengatakan bahwa kondisi sarana dan prasarana yang ada di PPLP sudah tidak layak dan belum ada anggaran untuk merenovasi atau memperbaiki kondisi sarana dan prasarana yang ada. Sementara salah satu faktor penunjang dalam menunjang prestasi olahraga adalah satu faktor penting dalam menunjang prestasi dibutuhkan sarana dan prasarana yang memadai dan layak untuk kegiatan latihan dan ivent-ivent olahraga (Handoko, 2009).

Sementara kebijakan pendanaan yang merupakan kunci keberhasilan organisasi mulai dari perencanaan, pengorganisasian, program latihan, sarana dan prasarana, sistem akademik semuanya tergantung pada ketersediaan anggaran yang memadai untuk menunjang pelaksanaan kegiatan tersebut. Pendanaan operasional PPLP bersumber dari APBN sedangkan untuk kegiatan kejuaraan dan lomba untuk ivent-ivent tertentu seperti kejuaraan antar PPLP, Pekan Olahraga Pelajar Nasional (POPNAS), Pekan Olahraga Pelajar Antar Wilayah (POPWIL) semua kebutuhan anggaran bersumber pada APBD Propinsi. Ketersediaan anggaran yang ada sangat terbatas, sehingga tidak dapat mengakomodir semua kegiatan yang akan didanai. Oleh karena itu kebijakan PPLP melalui Dinas Kepemudaan dan Olahraga Propinsi Sulawesi Tenggara adalah memaksimalkan anggaran yang ada dengan memprioritaskan kegiatan-kegiatan atau ivent yang prioritas dan mempunyai potensi untuk menyumbangkan prestasi bagi atlet binaan PPLP. Dilain pihak keterlibatan pihak ketiga sebagai sponsorship juga sangat terbatas, sehingga PPLP mengalami kendala dana untuk pembinaan atlet PPLP.

Kebijakan rekrutmen atlet dan pelatih, sistem akademik dan program latihan sudah berjalan dengan baik. Pelatih dan asisten pelatih yang direkrut melalui prosedur yang ideal. Sehingga out put dalam melaksanakan tugas-tugas terkait dengan program latihan disusn berdasarkan kompetensi yang ada. Program latihan dibuat berdasarkan kalender akademik nasional berdasarkan ivent-ivent kejuaraan yang telah tercantum secara nasional. PPLP di setiap daerah menyesuaikan dengan kondisi tersebut. Program latihan dijabarkan dalam kegiatan tahunan, bulanan dan mingguan, sehingga jadwal latihan yang telah dibuat menjadi prosedur baku yang menjadi tugas pokok pelatih dan asisten pelatih dalam menyusun program latihan tersebut. Aktivitas yang terjadi secara rutin dan berkesinambungan sehingga pelaksanaan program latihan ini mencapai hasil yang baik.

Rekrutmen atlet dan pelatih merupakan komponen yang sangat strategis dalam menentukan prestasi atlet. Proses rekrutmen atlet dilakukan secara terbuka untuk memenuhi ketentuan yang berlaku dan didasarkan atas kebutuhan organisasi, ruang, latar belakang pendidikan, tempat/motivasi peningkatan prestasi, derajat 
komitemn, dedikasi dan kesehatan fisik. Atlet/siswa yang mengikuti seleksi harus memenuhi persyaratan administrasi dan persyaratan teknis. Dalam seleksi melibatkan pihak-pihak seperti Dinas Pendidikan, Dinas Kepmudaan dan Olahraga, Indik organisasi Cabang Olahraga, dan KONI. Hasil seleksi diumumkan melalui penggilan yang ditanda tangani oleh Dinas Kepemudaan dan Olahraga Propinsi Sulawesi Tenggara. sementara dalam rekrutmen pelatih dan asisten pelatih harus memenuhi beberapa persayaratan antara lain : (a). sehat jasmani dan rohani; (b) memiliki komitmen dan motivasi tinggi untuk melatih siswa PPPLP; (c). Memeiliki kompetensi, seryifikat atau lisensi sesuai dengan aturan kecabangan dan pengalaman sebagai pelatih pada tingkat nasional atau internasional; (d). Dalam melatih pelatih atau asisten pelatih telah mendapat rekomendasi dari induk organisasi cabang olahraga sesuai dengan persyaratan dan ketetapan yang telah ditentukan; (e). Setiap pelatih mengikuti tata cara penerimaan dan kriteria pelatih yang telah ditetapkan; (f). Wajib membuat program latihan secara periodik; (g). Berkoordinasi dengan bidang kepaltihan dalam pelaksanaan tugasnya; $(\mathrm{h})$. Mencatat hasil latihan harian; (i). Melakukan tes dan evaluasi terhadap perkembangan atlet/siswa; (j). Merencanakan dan melaksanakanuji coba dan pertandingan sesuai dengan program latihan; dan (k). Melaporkan perkembangan latihan dan prestasi atlet/siswa kepada penanggungjawab; (l) memahami, mempromosikan dan melakukan semua ketentuan dan peraturan dopping. Keputusan diterimanya atlet/siswa dan pelatih dan asisten pelatih dituangkan dalam Surat Keputusan Kepala Dinas Kepemudaan dan Olahraga Propinsi Sulawesi Tenggara.

Sistem akademik Kebijakan pembinaan atlet dari dimensi akademik dikoordinir oleh Koordinator Bagian Akademik PPLP. Kegiatan bidang akademik PPLP antara lain mengurus administrasi sekolah, mengawasi dan memantau kegiatan belajar siswa/atlet PPLP di sekolah maupun di asrama, menfasilitasi siswa/atlet yang mendapat masalah dalam proses belajar, melaporkan perkembangan belajar siswa/atlet secara periodik kepada ketua pelaksana. Pembelajaran di PPLP melibatkan tenaga pengajar yang memenuhi persayaratan kualifikasi akademik yang sesuai dengan bidang keahlian masing. Sistem pembelajaran dilakukan secara terprogram dan terrencana sesuai dengan cabang olahraga yang diminati.

Terdapat 3 faktor pengaruh yang menyebakan hal tersebut sebagaimana telah diuraikan sebelumnya pada kerangka pikir antara lain : (a) keterampilan aparat; (b) pengawasan dari atasan dan (c). Insentif moral. Terdapat 3 faktor pengaruh yang menyebakan hal tersebut sebagaimana telah diuraikan sebelumnya pada kerangka pikir antara lain : (a) keterampilan aparat; (b) pengawasan dari atasan dan (c). Insentif moral.

Keterampilan sebagai kemampuan seseorang menerapkan pengetahuan dalam bentuk tindakan (Dessler, 2009). Sementara itu Wardiah, dkk (2008) mengatakan bahwa terdapat hubungan yang positif antara keterampilan dan prestasi kerja karyawan. Karyawan yang memiliki keterampilan cenderung mencapai prestasi kerja yang optimal. Demikian pula dengan pandangan Triton (2009) karyawan yang memiliki tingkat keterampilan yang tinggi cenderung mencapai kinerja yang lebih baik dibandingkan dengan karyawan yang memiliki keterampilan yang rendah. Menurut Rober L Katz (1978) dalam Silalahi (2013) ada tiga tipe dasar keterampilan manajerial, yaitu : (1). Keterampilan teknik, yaitu kemampuan atau kompetensi spesifik untuk menggunakan teknik-teknik, alat-alat, prosedur-prosedur, metode-metode atau pengetahuan-pengetahuan tentang lapangan yang dispesialisasi secara benar dan tepat dalam pelaksanaan tugasnya; (2). Keterampilan manusia, yaitu kemampuan untuk memahami atau memotivasi orang lain, sebagai individu atau dalam kelompok. Keterampilan hubungan manusia adalah jauh lebih penting dari keterampilan teknis. Kemampuan ini berhubungan dengan kemampuan menseleksi personalia, menciptakan dan membina hubungan baik, memahami orang lain, memberi motivasi dan bimbingan dan mempengaruhi para pekerja, baik secara individu atau kelompok. (3). Keterampilan konseptual, yaitu kemampuan mengkoordinasikan dan mengintegrasikan 
semua kepentingan-kepentingan dan aktivitas-aktivitas organisasi atau kemampuan mental mendapatkan, menganalisis, menginterpretasi informasi yang diterima dari berbagai sumber.

Fungsi pengawasan atau pengendalian organisasi sangat penting dalam rangka untuk mengetahui apakah tugas-tgas terlaksana efektif dan sumber daya yang digunakan efisien atau tujuan organisasi tercapai secara efektif dan efisien. Pengawasan merupakan fungsi manajer untuk menjamin bahwa organisasi dan tindakantindakan anggotanya bergerak ke arah tujuan yang sudah ditetapkan. Fungsi pengawasan menjamin untuk pencapaian tujuan. Oleh karena itu pengawasan sangat penting karena merupakan jaringan terakhir dalam fungsi-fungsi manajemen. Pengawasan ini menjadi cara manajer untuk mengetahui apakah tujuan organisasi tercapai atau tidak dan harus ditemukan jawabannya (John A, and Robbinson, 1989).

Insentif moral menurut Hulsmann (2006) sebagai kondisi-kondisi dalam diri individu yang tumbuh untuk memotivasi manusia. Insentif moral menunjuk pada kondisi-kondisi moral yang memotivasi tindakan manusia. Istilah motivasi secara etimologi berasal dari kata Latin movere yang berarti menggerakkan. Jadi, motivasi berarti hal-hal yang mendorong atau menggerakkan seseorang untuk melakukan sesuatu (Helms, 2006). Dalam penggunaan sehari-hari, motivasi adalah tentang mengantarkan orang untuk bekerja dengan semaksimum kemampuannya (Kitchin, 2010). Konsep motivasi telah didefinisikan dengan berbagai cara oleh para pakar. Rilley (2005 mendefinisikan motivasi sebagai alasan-alasan yang mendasari perilaku yang ditandai oleh keinginan atau kemauan. Gibson et al. (2012:87) menyatakan bahwa motivasi berhubungan dengan tiga hal, yakni: (1) arah perilaku, (2) kekuatan respons setelah karyawan memilih mengikuti tindakan tertentu, dan (3) ketahanan perilaku, atau berapa lama orang itu terus-menerus berperilaku menurut cara tertentu.

\section{KESIMPULAN}

Berdasarkan hasil studi empiris dan analisis penulis dan pembahasan dapat disimpulkan : (1). Kebijakan pembinaan atlet yang mencakup perencanaan, pengorganisasian, program latihan, sarana dan prasarana, rekrutmen atlet dan pelatih, sistem akademik dan pendanaan di PPLP Dinas Kepemudaan dan Olahraga Propinsi Sulawesi Tenggara secara umum belum berjalan dengan baik. Dari tujuh dimensi kebijakan yang dianalisis 4 dimensi yang belum berjalan dengan baik antara lain : kebijakan perencanaan, pengorganisasian, ketersediaan sarana dan prasarana dan penganggaran. Sementara 3 dimensi kebijakan yang sudah berjalan dengan baik adalah sistem rekrutmen atlet dan pelatih, sistem akademik dan program latihan. (2). Terdapat 3 (tiga) faktor yang mempengaruhi efektivitas kebijakan pembinaan atlet di Pusat Pendidikan dan Latihan Pelajar (PPLP) Dinas Kepemudaan dan Olahraga Propinsi Sulawesi Tenggara ketiga faktor tersebut adalah : (a). Faktor keterampilan (keterampilan teknik, keterampilan hubungan manusia dan keterampilan konseptual) masih rendah. (b). Faktor pengawasan dari institusi yang lebih tinggi masih lemah. (c). Faktor disinsentif moral pejabat. Pejabat pembina PPLP memiliki insentif moral yang kuat untuk menggunakan sumber daya anggaran sebagaimana yang seharusnya yakni dengan cara menyusun program kerja dengan tidak melibatkan perangkat PPLP. 


\section{REKOMENDASI}

Impilkasi penelitian ini diharapkan untuk perbaikan kebijakan pembinaan atlet khususnya pada dimensi perencanaan, pengorganisasian, sarana dan prasarana serta pendanaan dan perlunya pendidikan dan pelatihan khusus bagi pejabat dan staf PPLP untuk meningkatkan keterampilan teknik, keterampilan hubungan manusia dan keterampilan konseptual yang akan mendukung pelaksanaan tugas dan fungsinya di PPLP, perbaikan pola pengawasan yang rutin dan berkesinambungan oleh pejabat berwenang dalam rangka koreksi, masukan, evaluasi dan umpan balik bagi pejabat dan staf PPLP dan perbaikan tata kelola dengan meningkatkan komitmen dan kepedulian untuk mewujudkan PPLP yang kuat dan bermartabat.

\section{DAFTAR PUSTAKA}

\section{Buku}

Anonim. 2017. Pedoman Pengelolaan Pusat Pendidikan dan Latihan Olahraga Pelajar. Asisten Deputi Pengelolaan Pembinaan Sentra dan Sekolah Khusus Olahraga. Deputi Bidang Pembudayaan Olahraga. Kementerian Pemuda dan Olahraga Republik Indonesia. Jakarta.

Atmoseoprapto, Kisdarto. 2001. Menuju SDM Berdaya. Edisi Pertama. Jakarta: PT Gramedia.

Denhardt, R. B., and Denhardt, J. V., 2006. Public Administration: An Action Oriented. Belmont: Thomson Higher Education.

Drucker Peter F. 2001. The Esential Drucker : In One Volume The Best of Sixty Years of Peter Druker's Essenial Writtings on Managemen. Butterworth and einemann; HBS, Harper Collins Publisher.

Dunn, Willain N. 2003. Pengantar Anaisis Kebijakan Publik. Yogyakarta : Gadjah Mada University Press.

Dye, Thomas R., 2001. Top Down Policymaking. New York: Chatham House Publishers.

Fester, Bill, S and Karen, S. 2001. Pembinaan untuk Meningkatkan Kinerja Karyawan. Jakarta: Ramelan.

Gibson, James L., John M. Ivancevich, James H. Donnelly, Jr., and Robert Konopaske. 2012. Organizations: Behavior, Structure, Processes. Fourteenth Edition. Published by Mc Graw-Hill, a Business unit of The Mc Graw-Hill Companies, Inc., 1221 Avenue of The Americas, New York, NY.

Geurts, T., 2012. Public Policy Making: The 21st Century Perspective, Apeldoorn, The Netherlands: Be Informed, online pada www.beinformed.com

Handoko, T Hani. 2009. Manajemen "Edisi 2". Yogyakarta: BPFE-Yogyakarta.

Harsuki. 2003. Perkembangan Olahraga Terkini. Jakarta: PT Raja Grafindo Persada.

Hulsmann, Jorg Guido, 2006. The Political Economy of Moral Hazard. Czech Journal Politica Economie. February 2006

ICAEW, 2012. Acting in The Public Interest: A Framework for Analysis Market Foundations Initiative. London: ICAEW. Diakses dari icaew.com/marketfoundations

Kitchin, D., 2010. An Introduction to Organisational Behaviour for Managers and Engineers: A Group and Multicultural Approach. Burlington: Elsevier Ltd. 
Koontz, H and Weichrich, H. 1993. Management A Global Prespective. Mc. Graw-Hill. Inc,.

Kraft, Michael E., Scott R. Furlong, 2004. Public Policy: Politics, Analysis, and Alternatives. Washington: CQ Press.

Lubis, Johansyah dan Heryanty Evalina, 2007. Latihan Dalam Olahraga Profesional. Jakarta: Badan Pengembangan dan Pengawasan Olahraga Profesional Indonesia.

Lubis, S.B. Hari dan Martani Husaeni. 1987. Teori Organisasi. Suatu Pendekatan Makro. Jakarta: PAU IlmuIlmu Sosial Universitas Indonesia.

Lutan, Rusli. dkk. 2000. Dasar - Dasar Kepelatihan. Departemen Pendidikan Nasional Direktorat Jenderal Pendidikan Dasar Dan Menengah Bagian Proyek Penataran Guru SLTP Setara D-III Tahun 2000

Miles, M.B and Huberman, A.M. 1994. Qualitative Data Analysis: An Expended Sourcebook, California: Sage Publications, Inc.

Mulyadi, D. 2015. Studi Kebijakan Publik dan Pelayanan Publik : Konsep dan Aplikasi Proses Kebijakan Publik dan Pelayanan Publik. Bandung : Alfa Beta.

Neuman, W. Lawrence. 2013. Metodologi Penelitian Sosial : Pendekatan Kualitatif dan Kuantitatif. Jakarta: PT. Indeks.

Park, William H., 2000. "Policy". In Defining Public Administration: Selections from the International Policy and Administration. Diedit oleh Jay M. Shafritz. Colorado: Westview Press.

Riley, S., 2005. Herzberg's Two-Factor Theory of Motivation Applied to the Motivational Techniques Within Financial Institutions. Senior Honors Theses/Dissertations. Eastern Michigan University. (Online). Diambil dari http://commons.emich.edu/honors/119

Rosenbloom, D.H and Robert S Kravchuk. 2005. Public Adinistration : Understanding Management, Politic and Law in The Public Sector. Boston: McGraw-Hill.

Silalahi, Ulber 2015. Metode Penelitian Sosial Kuantitatit. Bandung: PT Refika Aditama.

2013. Asas-Asas Manajemen. Bandung: PT Refika Aditama.

Spencer, Lyle M. Jr, and Signe Spencer (1993), Competence At Work, Models for Superior Performance. United States of Amerika: John Wiley \& Sons.Inc.

Sumaryadi, Nyoman. 2005. Efektivitas Implementasi Kebijakan Otonomi Daerah. Jakarta: Citra Utama.

Triton, P.B. 2009. Mengelola Sumber Daya Manusia. Yogyakarta: Penerbit Oriza.

Vigoda, E. 2002. The Legacy of Public Administration and Review. In Public Administration : An Interdiciplinary Crytical Analysis. Edited By Eran Vigoda. New York: Marcell Dekker, Inc.m pp 1-18.

Wibowo. 2015. Manajemen Kinerja. (Edisi Revisi). Jakarta: Raja Grafindo Persada.

, 2007. Manajemen Kinerja. Jakarta: Raja Grafindo Persada.

Wilson, Charter A., 2006. Public Policy: Continuity and Change. New York: McGraw-Hill.

$\underline{\text { Artikel dan Jurnal Ilmiah }}$

Abidin, H. Zainal. 2013. Pembinaan Olahraga Prestasi dan permasalahnnya. Hhtp://www.tribunews.com/tribuners/2013/12/15.

Pembinaan-olahraga-prestasi-danpermasalahnnya. Diakses pada tanggal 14 Maret 2018 
Deli, Y. 2014. Efektivitas Pembinaan dan Pelarihan Gelandangan dan Pengemis Dinas Sosial dan pemakaman Kota Pekan Baru. Jom FISIP. Volmue 2 Nomor 1. Oktober 2014.

Firdaus, Kamal. 2011. "Evaluasi Program Pembinaan Olahraga Tenis Lapangan di Kota Padang". Jurnal Media Ilmu Keolahragaan Indonesia (Online) Volume 1. Edisi 2. Halaman 127-132. ( http://journal.unnes.ac.id/nju/index.php/miki/articl /download/2027/214l, diunduh pada 28 Pebruari 2018)

Kusnanik, Nining Widyah. 2013. "Evaluasi Manajemen Pembinaan Prestasi PRIMA Pratama Cabang Olahraga Panahan di Surabaya". Jurnal IPTEK Olahraga. Vol. 15 (2): hal. 125-137.

Mulyadi, Agustanico Dwi. 2015. "Evaluasi Program Pembinaan Sepakbola Klub Persijap Jepara". Jurnal Ilmiah PENJAS. (Online) Vol. 1 (2): hal. l-18. (http://ejournal.utp.ac.id/index.php/JIP/article/vie w/323/318, diunduh pada 28 Pebruari 2018)

Aji, Tri. 2013. Pola Pembinaan Prestasi Pusat Pendidikan dan Latihan Pelajar (PPLP) Sepak Takraw Putra Jawa Tengah Tahun 2013. Jurnal Media Ilmu Keolahragaan Indonesia Volume 3. Edisi 1. Juli 2013. ISSN: 2088-6802.

\section{Peraturan Perundang-Undangan}

Surat Keputusan Pejabat Pembuat Komitmen Satuan Kerja Dinas Kepemudaan dan Olahraga Propinsi Sulawesi Tenggara Nomor 7 tahun 2017 tentang Pengurus, Pelatih, Asisten Pelatih dan Atlet PPLP 5 Cabang Olahraga Kegiatan Pengembangan Sentra Keolahragaan Program Keolahragaan Dinas Kepemudaan dan Olahraga Propinsi Sulawesi Tenggara Tahun Anggaran 2017; 